\title{
The Mutagenic and Chemical Properties of SRC-I Materials: A Status Report
}

\author{
R. A. Pelroy
}

January 1981

Prepared for the U.S. Department of Energy under Contract DE-AC06-76RLO 1830

Pacific Northwest Laboratory Operated for the U.S. Department of Energy by Battelle Memorial Institute 


\title{
NOTICE
}

This report was prepared as an account of work sponsored by the United States Government. Neither the United States nor the Department of Energy, nor any of their employees, nor any of their contractors. subcontractors, or their employees, makes any warranty, express or implied, or assumes any legal liability or responsibility for the accuracy. completeness or usefulness of any information, apparatus. product or process disclosed, or represents that its use would not infringe privately owned rights.

The views, opinions and conclusions contained in this report are those of the contractor and do not necessarily represent those of the United States Government or the United States Department of Energy.

\author{
PACIFIC NORTHWEST LABORATORY \\ operated by \\ BATTELLE \\ for the \\ UNITED STATES DEPARTMENT OF ENERGY \\ Under Contract DE-AC06-76RLO 1830
}

\author{
Printed in the United States of America \\ Available from \\ National Technical Information Service \\ United States Department of Commerce \\ 5285 Port Royal Road \\ Springtield, Virginia 22151
}

Price: Printed Copy $\$$

$\therefore$ Microfiche $\$ 3.00$

NTIS

- Pages Selling Price

$001.025 \quad \$ 4.00$

$026-050 \quad \$ 4.50$

051-075 \$5.25

$076-100 \quad \$ 6.00$

$101-125 \quad 56.50$

$126-150 \quad 57.25$

$151-175 \quad \$ 8.00$

$176-200 \quad \$ 9.00$

$201-225 \quad 59.25$

$226-250 \quad 59.50$

$251.275 \quad \$ 10.75$

$276-300 \quad \$ 11.00$ 
PNL-3604

UC-90d

\section{0}

THE MUTAGENIC AND CHEMICAL PROPERTIES

OF SRC-I MATERIALS: A Status Report

R. A. Pelroy, Editor

Contributors: D. S. Sklarew

A. Toste

B. W. Wilson

January 1981

Prepared for

the U.S. Department of Energy under

Contract DE-AC06-76RLO 1830

Pacific Northwest Laboratory

Richland, Washington 99352 
- 


\section{SUMMARY}

Process solvent (PS) and solid product (dissolved in organic solvent) produced by the Solvent Refined Coal (SRC-I) process at the Wilsonville pilot plant contain mutagenically active components against the Ames-Salmonella strains, Salmonella typhimurium TA98 and TA100. Ames-positive mutagens are apparently concentrated in the moderately polar to strongly polar chemical constituents of both materials. However, the dissolved solid product contains a much higher proportion of very strongly polar mutagens, and may be enriched in acidic--i.e., oxygen-containing mutagens. 


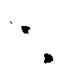

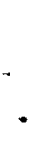


CONTENTS

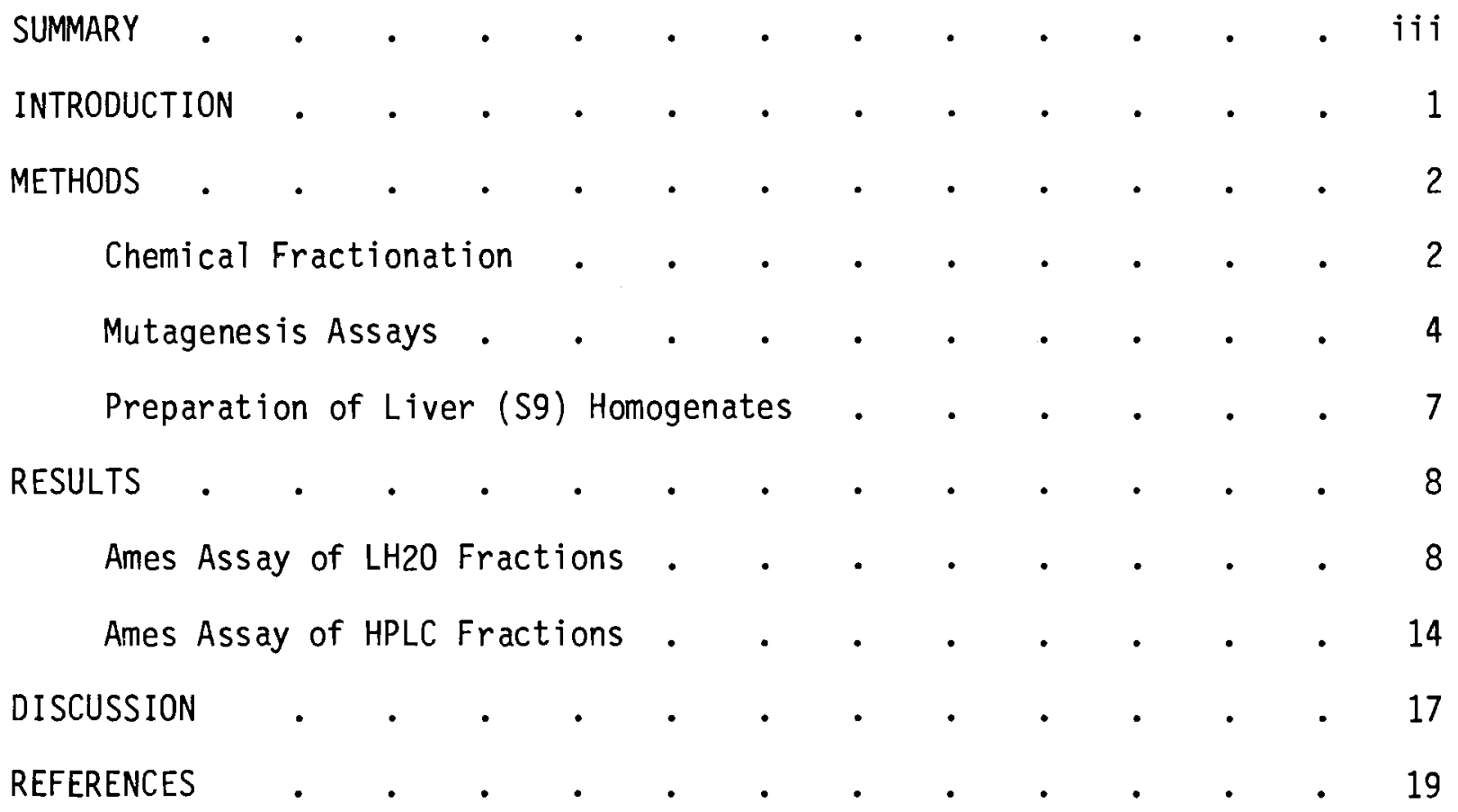

v 


\section{FIGURES}

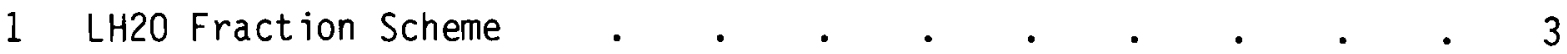

2 Ames Mutagenic Activity of LC Fractions of PS . . . . . $\quad$ • 15

3 Ames Mutagenic Activity of LC Fractions of the Organic

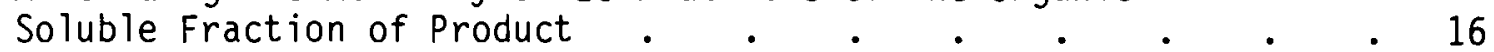

$\underline{\text { TABLES }}$

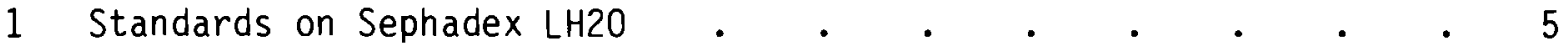

2 Standards on $\mathrm{NH}_{2}$ Column (HPLC) . . . . . . . . 6

3 Mutagen Phenotype of Ames Tester Strains Used to Bioassay SRC Materials . • • . . . . . • . . 7

4 Ames Mutagenicity for Four Test Strains Versus the PS . . . 9

5 Summary of Ames Bioassay Data for LH2O Sephadex Fractions from SRC-I Process Solvent . . . . . . . . 10

6 Ames Mutagenicity Data for Four Test Strains Versus the Organic Fraction from Product . . . . . . . . 12

7 Summary of Ames Bioassay Data for LH2O Sephadex Fractions from SRC-I Product Solubilized in Organic Solvents . . . 13 


\section{$\underline{\text { INTRODUCTION }}$}

The feasibility of fuel production by direct liquefaction of coal is currently under investigation in the United States. The Solvent Refined Coal Process I (SRC-I), one method of direct coal liquefaction, is at a pilot plant stage of development and is slated to enter the demonstration plant stage. Concomitant with the technological research required in this effort, biomedical and environmental research on the potential impact of SRC-I product process streams and wastes in the workplace and in the environment is also being carried out. Information obtained from this work may eventually aid design engineers in their effort to develop the SRC-I process in an environmentally acceptable fashion.

As part of this effort, SRC-I materials are being tested for their genetic activity in the Ames/Salmonella test system. Results from Ames assay have been shown to correlate with chemical carcinogenesis. The assay is used extensively as a screening test to identify materials for more time consuming and expensive small animal carcinogenesis tests $(1,8)$ and to correlate chemical composition with biological effect.

The work presented here was done on two SRC-I pilot plant materials: process solvent (PS) and extracts of the solid SRC-I product. The product was extracted both with organic and aqueous solvents, and the extracts assayed for mutagenicity. The PS and organic-solvent solubilized product were also fractionated by high-performance liquid chromatography (HPLC) and the fractions assayed for mutagenicity.

The choice of these two materials for this initial phase of mutagenesis testing of SRC-I materials was determined by two considerations: First, it is known that the high-boiling, high-molecular weight SRC distillates such as PS were mutagenically active in the Ames assay $(2,10,11,12,17)$. Lower boiling (low-molecular weight) distillate fractions were without genetic activity in the Ames assay. The PS is also a major process stream which gives rise to end products and also recycles through the process. Thus, PS constitutes a material of primary concern relative to work force exposure. The SRC-I solid product will leave the process facility and is, therefore, of both occupational health and environmental concern. 


\section{METHODS}

\section{Chemical Fractionation}

The SRC-I process solvent (PS) and organic solvent extractable chemicals from SRC-I solid product were fractionated by partition chromatography on Sephadex LH2O (Figure 1). The method employed was a modification of a scheme described by Klimisch and Stadler ${ }^{(7)}$ and further developed for fossil fuels by Jones, Guerin and Clark ${ }^{(6)}$. Sephadex LH2O was swelled in methanol:water (85:15) and packed in a $2.5 \mathrm{~cm} \times 30 \mathrm{~cm}$ glass column. SRC-I samples up to $1.5 \mathrm{~g}$ per column run were diluted with hexane and introduced onto the top of the Sephadex column. Chemical constituents in these materials were eluted sequentially with hexane, followed by 10 toluene in hexane, and finally by methanol. Each elution step was carried out with about $300 \mathrm{ml}$ of solvent.

Two different methods were used to add the solid product to the LH2O. In the first, $0.5 \mathrm{~g}$ of the finely ground solid product was dissolved in toluene/ methanol (3/1), added to dry Sephadex and stirred. This mixture was then dried under nitrogen until there was no liquid left. The Sephadex LH2O beads, containing the product, were then added "dry" to the top of a Sephadex column. Alternatively, $0.5 \mathrm{~g}$ of the dry ground solid product was added to dry Sephadex and stirred. Hexane was added to the dry mixture with stirring. The swelled material was added to the top of the column. In both cases sequential solution was used: $300 \mathrm{ml}$ hexane, $300 \mathrm{ml}$ toluene/hexane, $900 \mathrm{ml}$ methanol, $900 \mathrm{ml}$ toluene/methanol $(3: 1)$, and $300 \mathrm{ml} \mathrm{CHCl}_{3}$. Both methods produced equivalent results and Ames data obtained from the second method (i.e., direct addition of product to Sephadex) will be presented. 


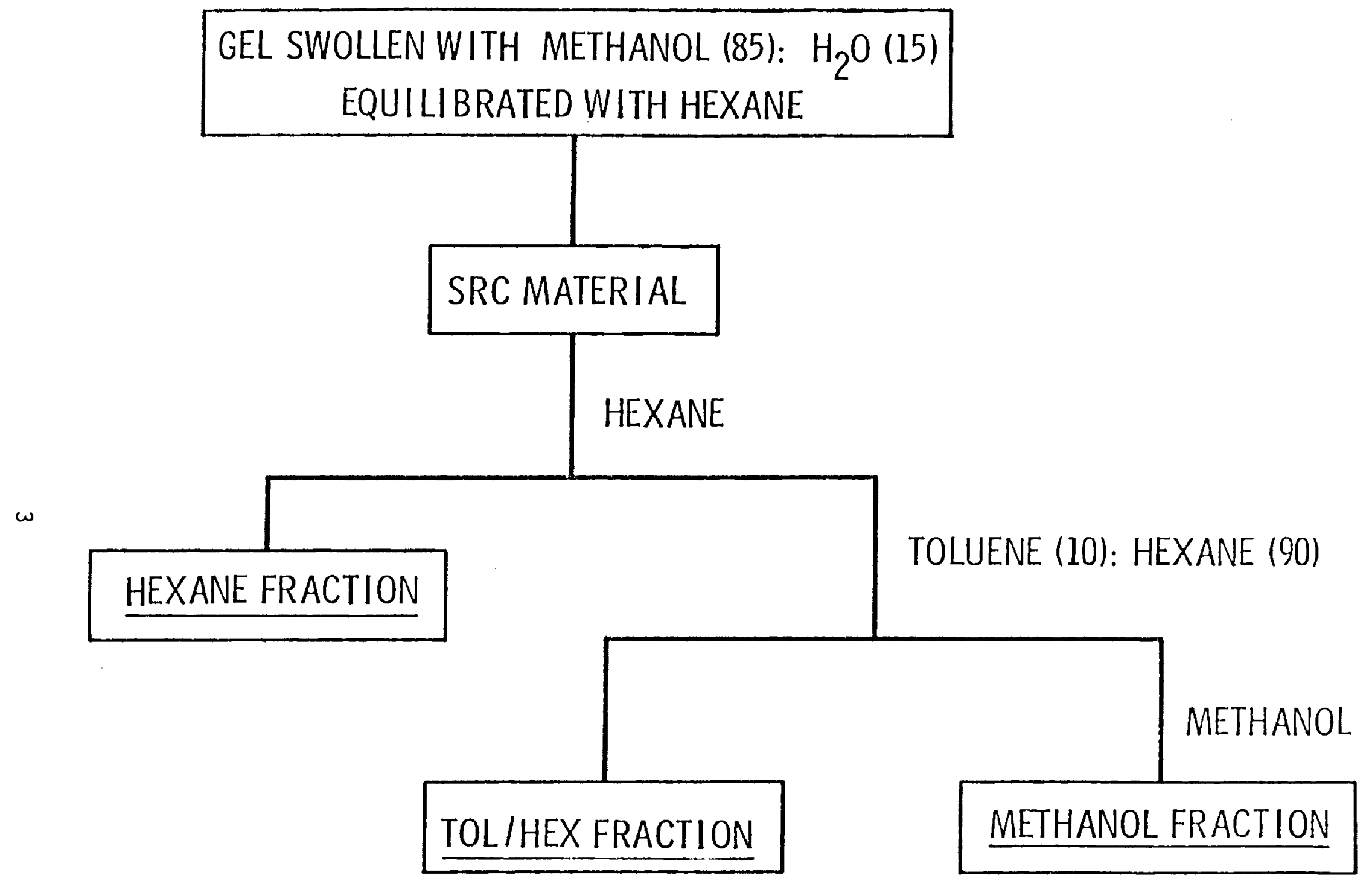

FIGURE 1. LH20 Fraction Scheme 
The Sephadex LH2O method separates essentially according to polarity, with the hexane fraction containing the least polar compounds, and the methanol fraction having compounds of moderate and high polarity. The toluene/hexane fraction is intermediate, comprised of compounds found in both the hexane and the methanol fractions.

Location of various standard compounds in the three solvent fractions is illustrated in Table 1. Polyaromatic hydrocarbon standards (PAH) were eluted in the LH2O hexane fraction. Several azaarene standards were eluted in the toluene/hexane fraction. Standard compounds eluting in the methanol fraction included polyaromatic primary amines (PAA) phenols and various bifunctional aromatic compounds (e.g., azaaromatic amines, diazapolycyclics, hydroxyazaarenes).

The chemical constituents in PS and those extracted with organic solvents from product were also fractionated by high performance liquid chromatography (HPLC) using a semipreparative normal phase amine column with a ternary solvent gradient. Samples thus obtained were dried and redissolved in DMSO for Ames bioassay. The solvent systems used in this separation procedure were as follows:

hexane, $100 \%(0-5 \mathrm{~min})$

linear gradient of methylene chloride in hexane (5-15 min) methylene chloride, $100 \%$ (15-20 min)

linear gradient of isopropanol in methylene chloride (20-30 min) isopropanol, 100\% (30-35 min).

The approximate elution times of a series of standard compounds are given in Table 2. Organic solvents used in these procedures were of spectral grade quality and were distilled in glass. The deionized water used for extraction of SRC-I product was first passed through a milli-Q system (Millipore) containing two ion exchange resins and two charcoal filters. All glassware was acid cleaned except the columns which were solvent rinsed with sonication. Mutagenes is Assays

Agar plate mutagenicity assays were performed as described by Ames et al. (1) using four of the Ames-Salmonella test strains: Salmonella 
TABLE 1. Standards on Sephadex LH20

Hexane Fraction

Aliphatic hydrocarbons

Polycyclic aromatic hydrocarbons

Nitrofluorene

Dibenzofuran

Dibenzothiophene

Fluorenone

Cyanophenanthrene

Toluene/Hexane Fraction

(Azaheterocyclics)

(Anthraquinone)

Methanol Fraction

Carbazole

Indoles

Primary Aromatic Amines

Azaaromatic amines

Diazaheterocyclics

Naphthols

Aminobenzothiadiazole

typhimurium TA98, TA100, TA1535 and TA1537. The mutagen phenotype defining these strains was determined in each experiment as shown in Table 3.

Dimethylsulfoxide (DMSO) was used for most of the work reported. It was used as the solvent for all chemical standard and complex chemical fractions derived from SRC-I. Dried extracts of water samples were redissolved in acetone for bioassay. In addition to the mutagens used to check on the phenotype of the test strains (Table 3), benzo[a]pyrene (Aldrich Co.) was also included as a positive control in every experiment. Negative controls included the 
TABLE 2. Standards on $\mathrm{NH}_{2}$ Column (HPLC)

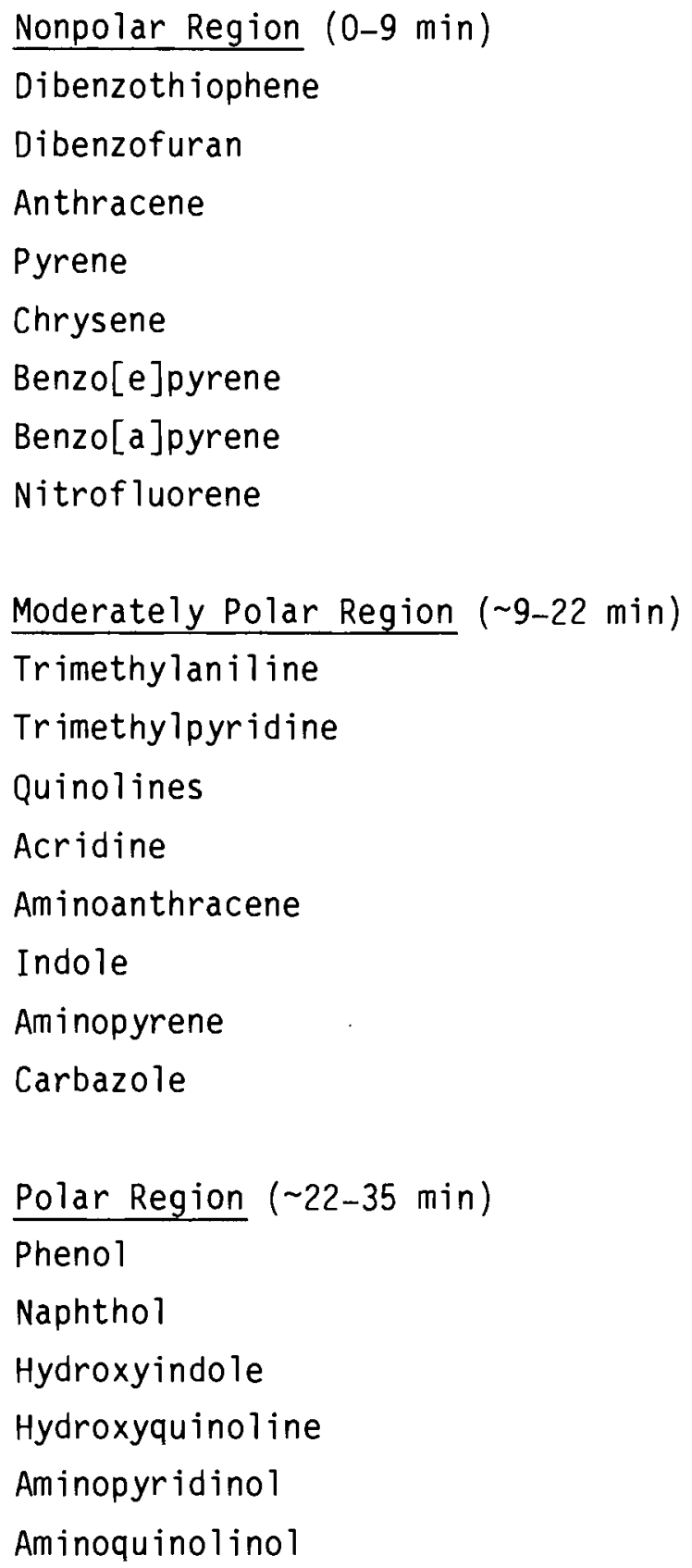

Ames/Salmonella typhimurium test strains, plus and minus microsomal enzymes (S9), and appropriate solvent controls. Mutagenic response, measured as revertant colonies were counted electronically using a Biotran II automated colony counter (New Brunswick Scientific Co., Inc., Edison, NJ). 
TABLE 3. Mutagen Phenotype of Ames Tester Strains used to Bioassay SRC Materials

\begin{tabular}{|c|c|c|c|c|c|c|}
\hline \multirow[b]{2}{*}{ Compound } & \multirow[b]{2}{*}{$\mu \mathrm{g} / \mathrm{Plate}$} & \multirow[b]{2}{*}{$\underline{59}$} & \multicolumn{4}{|c|}{$\begin{array}{c}\text { Response } \\
\text { for Ames Test Strain: }\end{array}$} \\
\hline & & & TA98 & TA100 & TA1537 & TA1535 \\
\hline 2-Aminoanthracene & 1 & + & $(+)$ & $(+)$ & $(+)$ & $(+)$ \\
\hline 9-Aminoacridine & 50 & + & $(-)$ & $(-)$ & $(+)$ & $(-)$ \\
\hline Nitrosoguanidine & 1 & - & $(-)$ & $(+)$ & $(-)$ & $(+)$ \\
\hline Dimethylbenzacridine & 10 & + & $(-)$ & $(+)$ & $(-)$ & $(-)$ \\
\hline
\end{tabular}

+ indicates a response in revertant colonies at least 2 times above background.

- indicates less than a twofold response above background.

The SRC-I chemical fractions in this study were assayed for mutagenicity at concentrations of $20,40,80,100,200$ and $500 \mu \mathrm{g}$, or $2,4,8,10,20$ and $50 \mu \mathrm{g}$ per petri plate. Each concentration was assayed in duplicate. Stock solutions of the various SRC-I chemical fractions, stored at $-80^{\circ} \mathrm{C}$ when not in use, were prepared at concentrations of $10,000 \mu \mathrm{g} / \mathrm{ml}$ in DMSO.

Specific mutagenic activity or potency was expressed as revertant colonies of S. typhimurium TA98/ug SRC-I material. This was estimated by linear regression analysis of dose-response data, i.e., as the slope of the regression line. A positive test was defined as having a maximum mutagenic response in rev TA98/ug twofold or greater above background, and a correlation coefficient 0.8 or above for the regression line. For quantative mutagenesis, the Ames experiments were replicated three times, and the average \pm SE of mutagenic potencies was calculated.

Preparation of Liver (S9) Homogenates

Induction of mutagen activating enzymes was done with Aroclor 1254 (Monsanto Chemical Corp.), $250 \mathrm{mg} / \mathrm{kg}$ body weight, injected intraperitoneally into male Wistar rats. Rats were sacrificed on the fourth day after injection. After sacrifice, livers were perfused with ice-cold $0.154 \mathrm{M} \mathrm{KCl}$ and removed for preparation of 59 homogenates, following standard procedures ${ }^{(1)}$. 


\section{RESULTS}

Ames Assay of LH2O Fractions

Table 4 is a summary of several experiments showing the mutagenic responses of four of the Ames tester strains, (S. typhimurium TA98, TA100, TA1535 and TA1537) to the LH20 fractions of PS.

Al1 fractions were screened with S. typhimurium TA98 (Table 4, column 3). The LH20 hexane fraction from PS was mutagenically inactive against TA98, but activity was detected for the toluene/hexane and methanol LH2O fractions of PS. No mutagenic response was observed without $\$ 9$ catalyzed metabolic activation (Table 4, column 4).

Because it was negative against $S$. typhimurium TA98, the LH20 hexane fraction of PS was tested against three other Ames/Salmonella typhimurium strains. These target cells can detect mutagens not detectable by TA98. All of these tests were performed with metabolic activation of the SRC materials. As shown, the hexane fraction was not mutagenic against any of these Ames tester strains (Table 4, columns 5-7). Therefore, either the neutral components from PS which were concentrated in this hexane fraction were not mutagenically active in the Ames test, or their mutagenicity was masked by the complex chemical environment of the hexane fraction.

The crude PS which was positive against TA98 was also assayed against the other Ames tester strains. Only strains TA98 and TA100 were responsive to this material, confirming previous observations with other synthet ic fuel mixtures $(3,4,10,11,13,14)$.

Since S. typhimurium TA98 was found to be a better strain than TA100 for quantitative mutagenesis work, it was used to estimate the potency of the crude PS and PS fractions. Results (Table 5) are taken from three replicate experiments using TA98 as the test strain. In the table, the (A) and (B) designations refer to duplicated LH2O fractionations. The mutagenic potencies of similar fractions were reasonably consistent between the (A) and (B) samples. In most cases, the error in these replicate measurements of mutagenic potency was between 10 to $20 \%$ of the ir mean value. 
TABLE 4. Ames Mutagenicity for Four Test Strains Versus the PS

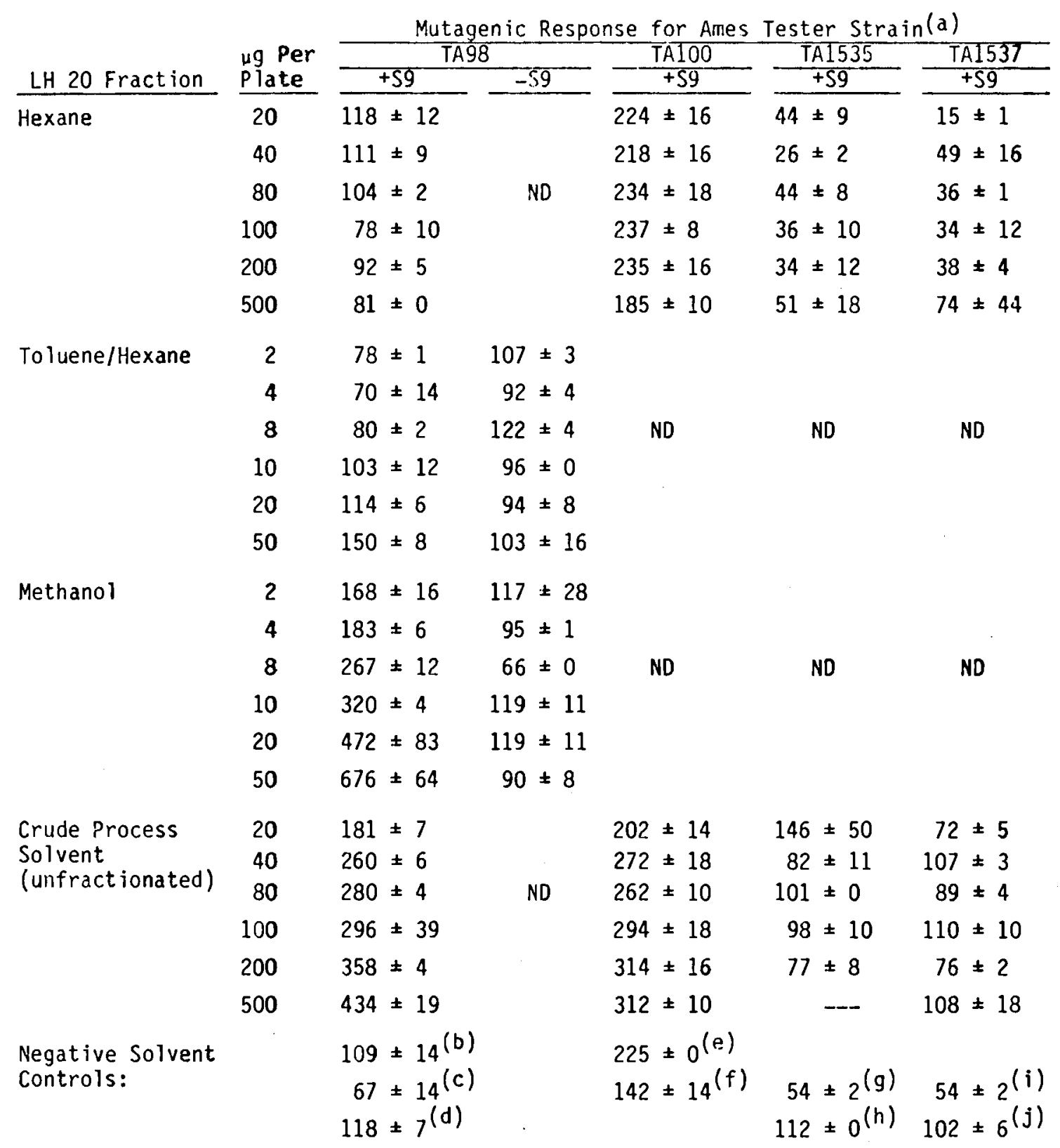

(a) Revertants per plate \pm SE, duplicate samples.

(b) Correspond to methanol fraction, TA98.

(c) Corresponds to toluene/hexane fraction, TA98.

(d) Corresponds to crude process solvent, TA98.

(e) Corresponds to hexane fraction, TAl00.

(f) Corresponds to crude process solvent, TA100.

(g) Corresponds to hexane fraction, TA1535.

(h) Corresponds to crude process solvent, TA1535.

(i) Corresponds to hexane fraction, TA1537.

(j) Corresponds to crude process solvent, TA1535.

ND Not Determined. 
TABLE 5. Summary of Ames Bioassay Data for LH2O Sephadex Fractions from SRC-I Process Solvent

\begin{tabular}{|c|c|c|c|c|c|}
\hline LH 20 Fraction & $\begin{array}{l}\text { Conc. Range } \\
\text { ( } \mu \text { g/plate) } \\
\end{array}$ & $\begin{array}{r}\text { Rev } \\
\mu g= \\
\text { (per }\end{array}$ & $\begin{array}{l}\text { TA98/ } \\
\pm \text { SE } \\
\text { plate) }\end{array}$ & wt \% & $\begin{array}{c}\text { Weighted } \\
\text { Activity (a) } \\
\end{array}$ \\
\hline Hexane (A) & 20 to 500 & & 0 & 75.0 & 0 \\
\hline Hexane (B) & 70 to 500 & & 0 & 74.0 & 0 \\
\hline Toluene/Hexane (A) & 2 to 50 & 5.87 & \pm 0.09 & 7.1 & 0.42 \\
\hline Toluene/Hexane (B) & 2 to 50 & 4.27 & \pm 2.01 & 8.2 & 0.35 \\
\hline Methanol (A) & 2 to 50 & 18.31 & \pm 1.88 & 16.5 & 3.02 \\
\hline Methanol (B) & 2 to 50 & 24.98 & \pm 1.06 & 15.4 & 3.85 \\
\hline Crude (unfractionated) & 20 to 500 & 0.54 & \pm 0.07 & 100 & 0.54 \\
\hline \multicolumn{6}{|l|}{ Sum (A) Fractions } \\
\hline
\end{tabular}

(A) and (B) refer to duplicate fractionations of process solvent by LH 20 Sephadex.

(a) Product of wt\% times specific mutagenic activity in rev TA98/ug.

Methanol fractions contained most of the mutagenic activity recovered from PS; i.e., $88 \%$ from fractionation $(A)$ and $92 \%$ from (B). The weight percent of the LH2O fractions (Table 5, column 4) multiplied times the ir specific mutagenic activities (Table 5, column 3) yielded a weighted specific mutagenic activity (column 5 ) which relates the contribution of a given LH2O fraction to the whole PS. These weighted activities, when summed, indicate the extent to which mutagenicities in given chemical fractions are additive (i.e., independent of composition).

The sum of mutagenicities in the individual LH2O fractions was greater for weighted specific mutagenic activity than the measured mutagenic activity 
of the crude unfractionated PS. These data suggest a large degree of interference in the expression of Ames mutagenicity in the crude PS that is removed by chemical fractionation by the LH2O procedure.

Tables 6 and 7 summarize Ames mutagenicity data for SRC-I solid product that had been completely solubilized in a series of organic solvents (see Methods). Qualitatively, the mutagenic responses of the solubilized product (Table 6) were the same as those obtained for PS. For example, both $\underline{S}$. typhimurium TA98 and TA100 were mutagenized by the toluene/hexane and methanol LH2O fractions, and the crude (unfractionated), solubilized product (Table 6; columns 3 and 4). All mutagenic activity was indirect (Table 6, column 3 versus 4). Assay of crude product showed little or no mutagenic activity using Ames tester strains TA1535 or TA1537. The hexane fraction did not show activity against any of the Ames tester strains used in these assays.

In contrast to results obtained for PS, LH2O chromatography of product required use of two additional solvents to remove highly polar compounds from the Sephadex columns. One of these, a chloroform fraction, was mutagenically active in the Ames test. The second, a toluene/methanol fraction, was mutagenically inactive against the four Ames tester strains.

Table 7 shows mutagenic potency for each of the LH2O fractions and for the unfractionated product. As for PS, potencies (or mutagenic specific activities) represent the mean $+S E$ from three replicate experiments. The two fractionations, labeled (A) and (B), were again compared to check on the mutagenic consistency of the same fractions obtained at different times (i.e., in duplicate LH2O fractionations).

Reproducibility of Ames data for any given mutagenic fraction was generally within $20 \%$ of its mean specific mutagenic activity value. However, more variation than this was seen between the same fractions from replicate $\mathrm{LH} 20$ runs--i.e., (A)'s versus (B)'s. Both (A) and (B) methanol fractions were more active than the other active LH2O fractions (i.e., toluene/hexane or chloroform fractions). However, the specific mutagenic activities of the toluene/ hexane and chloroform fractions varied so much between the (A) and (B) runs that it was impossible to assign a difference between these fractions in terms of their mutagenic specific activity. 
TABLE 6. Ames Mutagenicity Data for Four Test Strains Versus the Organic Fraction from Product

\begin{tabular}{|c|c|c|c|c|c|c|}
\hline \multirow[b]{2}{*}{ L.4 20 Fraction } & \multirow[b]{2}{*}{ yg Per Plate } & \multicolumn{5}{|c|}{ Mutagenic Response for Ames Tester Strain (a) } \\
\hline & & +59 & -59 & $\frac{\text { TA100 }}{+59}$ & $\frac{\text { TA1535 }}{+59}$ & $\frac{\text { TA1537 }}{+59}$ \\
\hline \multirow[t]{6}{*}{ Hexane } & 20 & $145 \pm 6$ & & $182 \pm 2$ & $48 \pm 11$ & $25 \pm 1$ \\
\hline & 10 & $172 \pm i 3$ & & $201 \pm 9$ & $35 \pm 1$ & $56 \pm 22$ \\
\hline & 80 & $187 \pm 17$ & ND & $230 \pm 8$ & $48 \pm 2$ & $57 \pm 10$ \\
\hline & 100 & $174 \pm 20$ & & $244 \pm 10$ & $48 \pm 14$ & $56 \pm 4$ \\
\hline & 200 & $236 \pm 8$ & & $264 \pm 15$ & $90 \pm 12$ & $88 \pm 1$ \\
\hline & 500 & $231 \pm 40$ & & -- & --- & $28 \pm 4$ \\
\hline \multirow[t]{6}{*}{ Toluene/Hexane } & 2 & $146 \pm 16$ & $114 \pm 20$ & & & \\
\hline & 4 & $174 \pm 9$ & $96 \pm 5$ & & & \\
\hline & 8 & $248 \pm 10$ & $74 \pm 1$ & ND & ND & ND \\
\hline & 10 & $300 \pm 40$ & $101 \pm 15$ & & & \\
\hline & 20 & $407 \pm 17$ & $92 \pm 2$ & & & \\
\hline & 50 & $560 ̄ \pm 48$ & $114 \pm 10$ & & & \\
\hline \multirow[t]{6}{*}{ Methanol } & 2 & $142 \pm 4$ & $136 \pm 20$ & & & \\
\hline & 4 & $217 \pm 9$ & $108 \pm 20$ & & & \\
\hline & 8 & $338 \pm 52$ & $110 \pm 6$ & ND & ND & ND \\
\hline & 10 & $434 \pm 48$ & $100 \pm 4$ & & & \\
\hline & 20 & $720 \pm 34$ & $76 \pm 4$ & $\cdot$ & & \\
\hline & 50 & $1201 \pm 92$ & $91 \pm 7$ & & & \\
\hline \multirow[t]{6}{*}{ Chloroform } & 2 & $112 \pm 10$ & & & & \\
\hline & 1 & $137 \pm 2$ & & & & \\
\hline & 3 & $172 \pm 18$ & ND & ND & ND & ND \\
\hline & 10 & $204 \pm 5$ & & & & \\
\hline & 20 & $264 \pm: 6$ & & & & \\
\hline & 30 & $526 \pm 38$ & & & & \\
\hline \multirow[t]{6}{*}{-oluene/Metinanol } & 20 & $123 \pm 4$ & & $i 32 \pm 2$ & $89 \pm 4$ & $78 \pm 5$ \\
\hline & 40 & $110 \times 1$ & & $20: \pm 9$ & $90=8$ & $104 \pm 30$ \\
\hline & 30 & $129 \pm 1$ & ND & $230 \times 8$ & $111 \pm 3$ & $112 \pm 3$ \\
\hline & $: 00$ & $:: 3=8$ & & $244 \pm 10$ & $124=10$ & $104 \pm 12$ \\
\hline & 200 & $121 \pm 3$ & & $264 \pm 15$ & $109 \pm: 9$ & $152 \pm 6$ \\
\hline & 500 & $106 \pm:$ & & --- & -- & --- \\
\hline \multirow{6}{*}{$\begin{array}{l}\text { Erude Product } \\
\qquad \text { infractionated }\end{array}$} & 20 & $154 \pm 78$ & & $\mathrm{i} 76 \pm \mathrm{i} 0$ & $146 \pm 50$ & $74 \pm 13$ \\
\hline & 40 & $350 \times 50$ & & $254=29$ & $82 \times 11$ & $140 \pm 10$ \\
\hline & 80 & $596=20$ & & $284 \times 12$ & $101 \neq 0$ & $102 \pm 1$ \\
\hline & 100 & $638 \pm 16$ & & $307 \pm 15$ & $98 \pm 10$ & $86 \pm 8$ \\
\hline & 200 & $896 \pm 62$ & & $390 \pm 53$ & $170 \pm 8$ & $107 \pm 38$ \\
\hline & 500 & $1105=14$ & & $1198 \pm 29$ & --- & \\
\hline $\begin{array}{l}\text { Vegative Solvent } \\
\text { Controi }\end{array}$ & -- & $109 \pm 14$ & $125=0$ & $230=3$ & $\begin{aligned} 50 & \pm 5 \\
: 12 & \pm 0(0)\end{aligned}$ & $\begin{aligned} 54 & \pm 2 \\
.02 & \pm 6(c)\end{aligned}$ \\
\hline
\end{tabular}

(a) Revertants per piate $\pm S E$, dupi icate samples.

(b) Corresponos to toluene/methanol eraction and crude product versus TA1535.

(c) Corresponds to toluene/methanol fraction and crude product versus TAl537.

ND Not Determined. 
TABLE 7. Summary of Ames Bioassay Data for LH2O Sephadex Fractions from SRC-I Product Solubilized in Organic Solvents

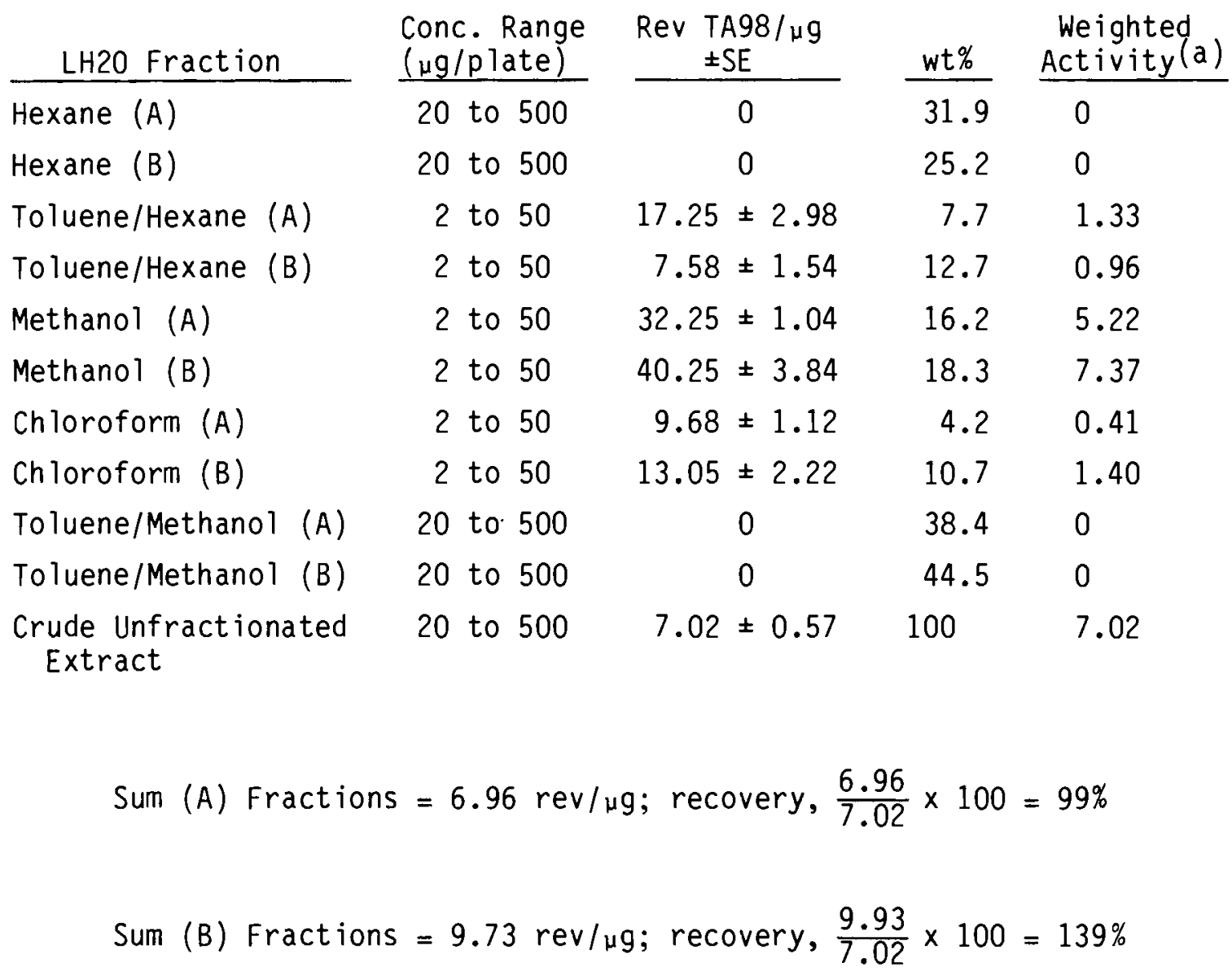

(A) and (B): See Table 2 .

(a) See Table 2 .

Weighted specific mutagenic activities (Table 7, column 5) again showed that most of the mutagenicity recovered from the product by LH2O chromatography was found in the methanol fractions [i.e., 75\% for (A) and 74\% for (B)]. Compared to the unfractionated (solubilized) product, recoveries of mutagenicity in the LH2O fractions ranged from $99 \%$ for (A) to $139 \%$ for (B). These data suggest that interference with mutagenicity measurements by Ames assay was not as great for the unfractionated, solubilized product as it was for the unfractionated PS. 
Ames Assay of HPLC Fractions

The HPLC separation of components in PS and SRC-I solid product revealed quantitative differences in the mutagens in these two SRC-I complex mixtures (Figures 2 and 3 ). Mutagenicity of PS (Figure 2) was associated mainly (i.e., ca $80 \%$ of recovered mutagens) with moderately polar chemical constituents that elute with retention times similar to nitrogen heterocycles and primary aromatic amines (PAA). A smaller mutagenic component eluted in an HPLC region characterized by strongly polar constituents; e.g., phenols, mixed nitrogen compounds containing phenolic groups.

Mutagenic activity of product (Figure 3) was more diffuse with the main component of activity (ca 58\%) in the strongly polar LC region, and somewhat less (ca 35\%) in the moderately polar to strongly polar regions, and the sma 11est amount of mutagenic activity in the moderately polar region (ca $13 \%$ ). 

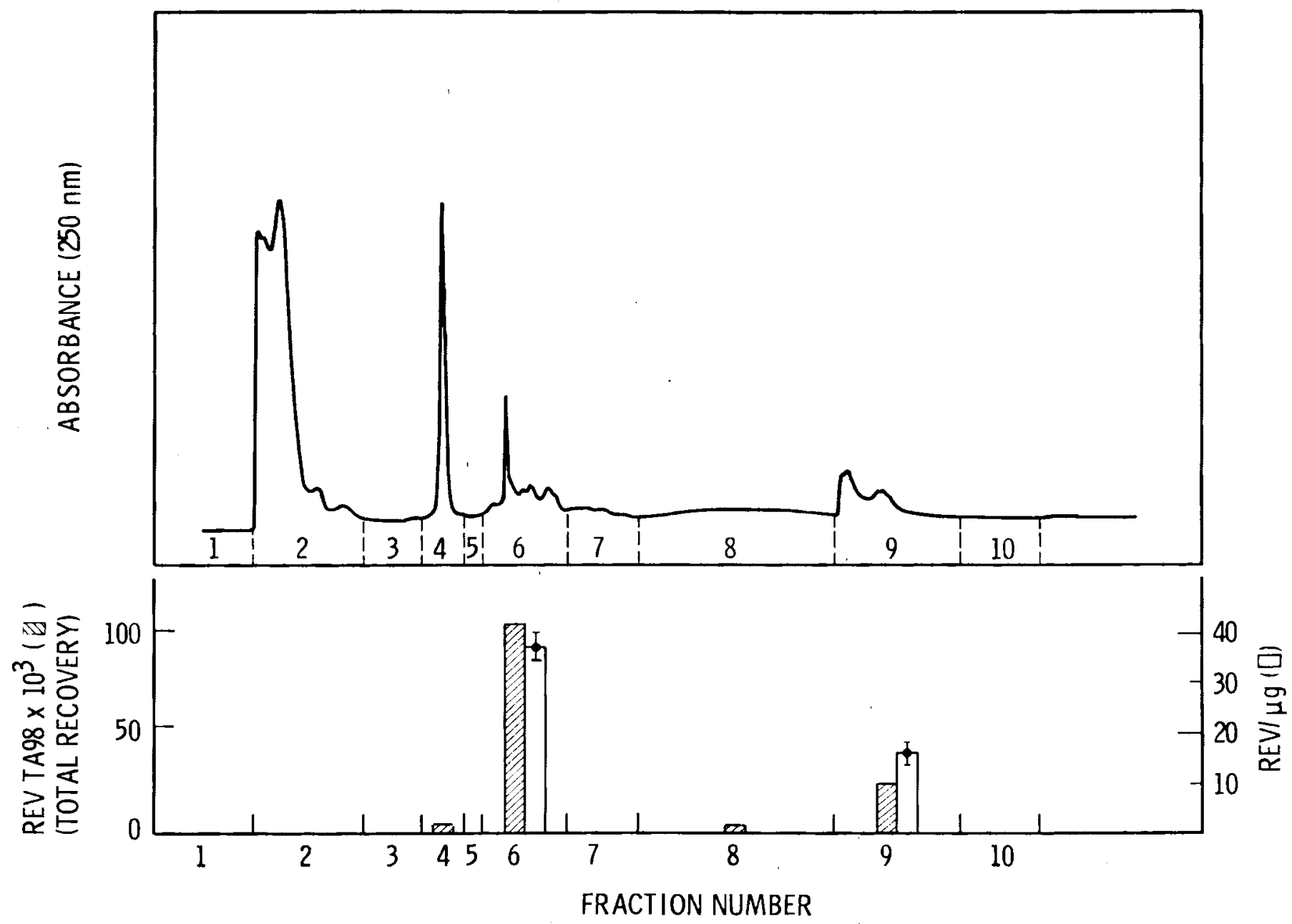

FIGURE 2. Ames Mutagenic Activity of LC Fractions of PS. Top panel: absorbance of $L C$ fractions at $250 \mathrm{~nm}$. Bottom panel: total mutagenic response in revertants TA98 (specific mutagenic activity in rev TA98/ $\mu \mathrm{g} \times \mu \mathrm{g}$ fraction) and specific mutagenic activity. 


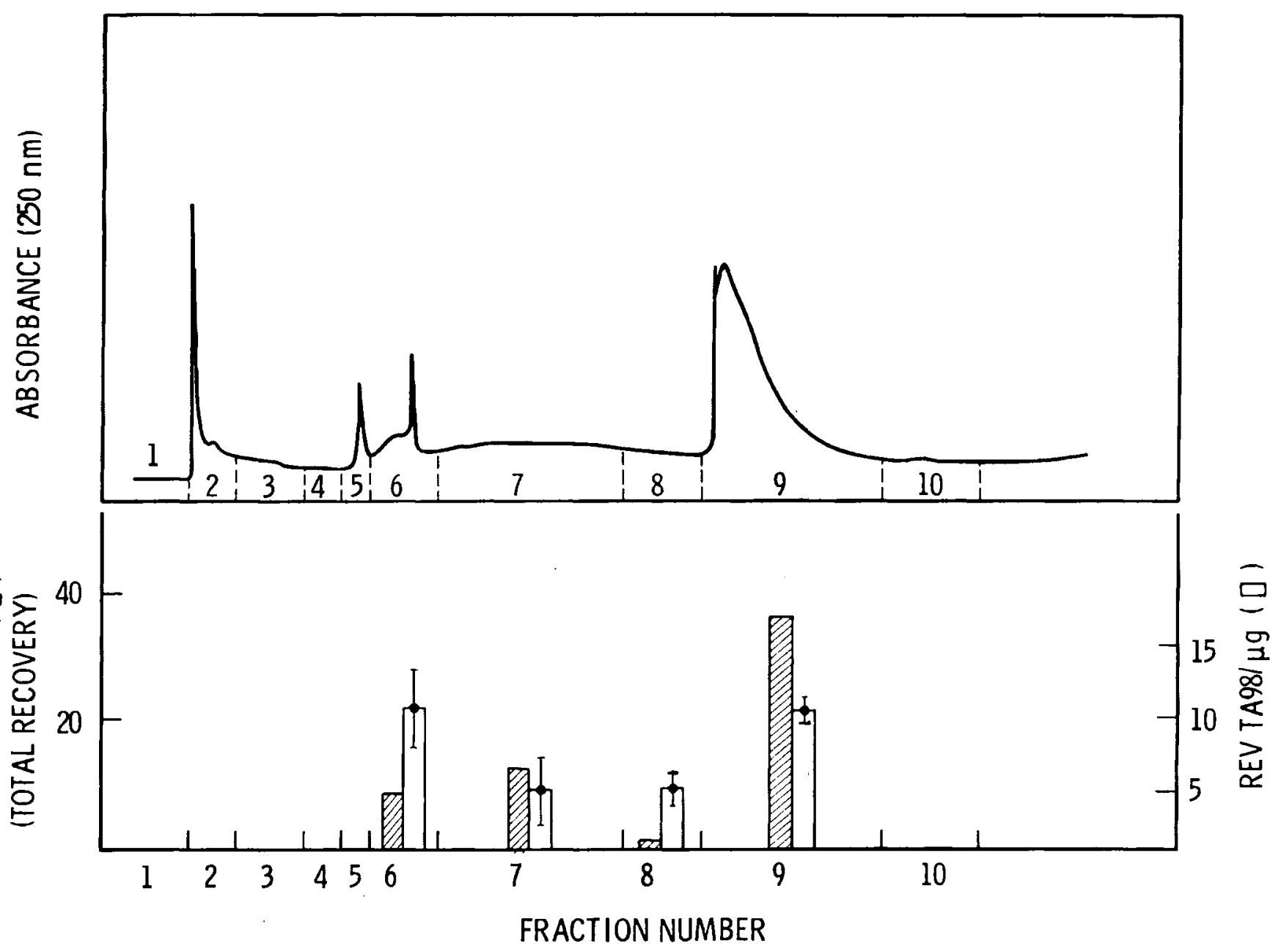

FIGURE 3. Ames Mutagenic Activity of LC Fractions of the Organic Soluble Fraction of Product. Top pane 1: absorbance of LC fractions at $250 \mathrm{~nm}$. Bottom pane 1: total mutagenic

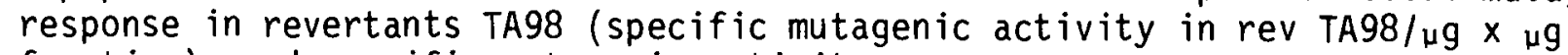
fraction); and specific mutagenic activity. 


\section{DISCUSSION}

Like other coal and oil shale synthetic fuels $(3,4,10,11,13,14)$, the highboiling SRC-I solid product and PS dissolved in organic solvent contained mutagens detectable in the Ames test. These mutagens were concentrated mainly in chemical fractions enriched in polar and moderately polar constituents and, in particular, in nitrogen-containing polycyclics.

As hydrocarbon mixtures, SRC high-boiling materials appear to be relatively rich in azaarenes $(5,9,16)$, neutral polyaromatic compounds $(16)$ and may also contain PAA $(12,17)$. Both azaarenes and PAA's would have been concentrated in the most mutagenically active chemical fractions from PS and in some of the less active fractions from product. The chemical characterization of both product and PS is now underway.

Also in common with previously reported results $(3,4,11,13,14)$, Ames mutagenicity, either of the crude SRC-I materials or their chemical fractions, was indirect and required a source of metabolic activation of the material. S. typhimurium TA98 was the most sensitive of four tester strains to mutagenes is induced by SRC-I product and PS. Thus, it was used for estimating the mutagenic potency of these SRC-I materials. Other synfuels, including coalderived jet fuels, were also shown to contain mutagens highly effective against $\operatorname{TA98}(3,4,11,13,14)$.

In relative terms, $P S$ and the organic solvent solubilized product were of approximately the same mutagenic potency as coal-derived jet fuels ${ }^{(4)}$ and SRC-II high-boiling range distillates $(10,12)$. They were also somewhat more genetically active in the Ames assay than shale oils and shale oil fractions $(10,11,13)$.

The PS and product differed in the way mutagenic activities distributed in LH2O and HPLC chemical fractions. This took the form of additional LH2O fractions required to recover all mutagenic activity for product, but was especially evident for the HPLC fractions of product. For example, in the PS, like other high-boiling range SRC liquids, mutagenically active constituents were concentrated in HPLC fractions identified with moderately polar nitrogen 
heterocyclics and PAA. On the other hand, more than half of the mutagenic activity recovered after chromatography of the product was localized in fractions identified with highly polar acidic constituents (e.g., phenolic compounds).

The Ames dose-response curves for unfractionated PS were nonlinear and yielded lower estimates of mutagenic potency than those obtained by summation of the weighted potencies of the PS chemical fractions. Conversely, the unfractionated (organic solvent solubilized) product had about the specific mutagenic activity of the sum of the chemical fractions from this material weighted for percent composition in the crude. 


\section{REFERENCES}

1. Ames, N., J. MCCann and E. Yamasaki. 1975. Methods for detecting carcinogens and mutagens with the Salmonella/mammalian-microsome mutagenicity test, Mutation Res., 347-364.

2. Biomedical studies on solvent refined coal (SRC II) liquefaction materials: A status report, PNL-3189, Pacific Northwest Laboratory, (NTIS).

3. Epler, J., T. Rao, C. Ho and M. Guerin. 1979. Identification of mutagenic components of basic fractions from crude oils, Environ. Mutagenes is, 1:172-180.

4. Epler, J., J. Young, A. Hardigree, T. Rao, M. Guerin, I. Rubin, C. Ho and B. Clark. 1978. Analytical and biological analyses of test materials from the synthetic fuel technologies. I. Mutagenicity of crude oils determined by the Salmonella typhimurium/microsomal activation system, Mutation Res., $57: \overline{265-276 .}$

5. Ho, C., B. Clark, M. Guerin, C. Ma and T. Rao. 1979. Aromatic nitrogen compounds in fossil fuels--a potential hazard, ACS Preprints, Div. Fuel Chem. $24: 281-291$.

6. Jones, A. R., M. R. Guerin, and B. R. Clark. 1977. Preparative-scale liquid chromatographic fractionation of crude oils derived from coal and shale, Anal. Chem., 49:1766-1771.

7. Klimisch, H. J., and L. Stadler. 1972. Trennung komplexer stoffgemische lipophiler und hydrophiler substanzen durch gel-verteilungschromatographie an Sephadex LH-20, J. Chromatogr., 67:291-297.

8. McCann, J., E. Choi, E. Yamasaki and B. Ames. 1975. Detection of carcinogens as mutagens in the Salmonella/microsome test: Assay of 300 chemicals, Proc. Nat. Acad. Sci. USA, 72:5139-5144.

9. Paudler, W., and M. Chaplen. 1979. Nitrogen bases in solvent-refined coal, Fuel, 58:775-778.

10. Pelroy, R., J. Cresto, and M. Petersen. 1978. Mutagenicity of shale oil and solvent refined coal products, Pacific Northwest Laboratory Annual Report. Part I: Biomedical Sciences, PNL-2850, NTIS, pp. 5.5-5.9, Springfield, Virginia 22151.

11. Pelroy, R., and M. Petersen. 1979. Use of Ames test in evaluation of shale oil fractions, Environ. Health Perspect., 30:191-203.

12. Pelroy, R., and A. Gandolfi. 1980. Use of a mixed function amine oxidase for metabolic activation in the Ames Salmonella assay system, Mutation Res., 72:329-334. 
13. Pelroy, R., and M. Petersen. 1978. Mutagenicity of shale oil components, in: Application of Short-term Bioassays in the Fractionation and Analysis of Complex Environmental Mixtures. (Waters, M., S. Nesnow, F. Huisingh, et al., eds) EPA-600/9-78-028, Research Triangle Park, NC: U.S. Environmental Protection Agency, 463-475.

14. Rao, T., J. Young, A. Hardigree, W. Winton and J. Epler. 1978. Analytical and biological analyses of test materials from the synthetic fuel technologies, II. Extended genetic and biochemical studies with mutagenic fractions, Mutation Res., 54:185-191.

15. Schiller, J. 1977. Nitrogen compounds in coal derived liquids, Anal. Chem., 49:2292-2294.

16. Schultz, R., J. Jorganson, M. Maskarinec, M. Novotny and L. Todd. 1979. Characterization of polynuclear aromatic and aliphatic fractions solventrefined coal by glass capillary gas chromatography/mass spectrometry, Fuel, 58: 783-789.

17. Wilson, B., R. Pelroy and J. Cresto. 1980. Identification of primary aromatic amines in mutagenically active subfractions from coal liquefaction materials. Mutation Res. 79:193-202. 


\section{DISTRIBUTION}

No. of

Copies

\section{OFFSITE}

A. A. Churm

DOE Patent Division

9800 South Cass Avenue

Argonne, IL 60439

27 DOE Technical Information Center

E. L. Alpen

Lawrence Berkeley Laboratory

University of $\mathrm{Cal}$ ifornia

Building 90, Room 2056

No. 1 Cyclotron Road

Berkely, CA 94720

K. Anderson

165 Scott Avenue

Morgantown, WV 26505

L. D. Attaway

1005 A Steet

Suite 405

San Rafael, CA 94901

N. F. Barr

Department of Energy

Office of Health and

Environmental Resarch

Mail Stop E-201

Washington, DC 20545

C. Berlin

Health Environmental

Review Division

U.S. Environmental

Protection Agency

Washington, DC 20460

R. W. Biles, Ph.D.

Exxon Corporation

Research and Environmental Health Division

Medical Department

P. 0. Box 235

East Millston, NJ 08873
No. of

Copies

J. R. Blair

Department of Energy

Office of the Assistant

Secretary for Environment

Washington, DC 20545

V. P. Bond

Brookhaven National Laboratory

Upton, Long Island, NY 11973

L. Brothers

Department of Energy

Office of Assistant Secretary for Environment

Washington, DC 20545

P. E. Brubaker

Exxon Corporation

Research and Environmental

Health Division

Medical Department

P. 0. Box 235

East Millston, NJ 08873

P. Buht

Department of Energy

Office of Fossil Energy

Mail Stop E-338, Germantown

Washington, DC 20545

W. W. Burr

Department of Energy

EV-30

Mail Stop E-301 GTN

Washington, DC 20545

C. E. Carter

Scientific Director

National Institute of Environmental Health Sciences

P. 0. Box 12233

Research Triangle Park, NC 27709 
No. of

Copies

M. Chartock

Science \& Public Policy Program

University of $0 \mathrm{klahoma}$

Norman, OK 73019

C. T. Chen

OSHA

U.S. Department of Labor

200 Constitution Avenue, NW

Washington, DC 20210

3 R. E. Clusen

Assistant Secretary for Environment

Department of Energy

Washington, DC 20545

K. Cowser

Oak Ridge National Laboratory

P. 0. Box X

Oak Ridge, TN 37830

2 D. Denny

Environmental Protection Agency

401 M Street, SW

Washington, DC 20460

2 Department of Library and Archives

James Nelson, Librarian

Box 537, Berry Hill

Frankfort, KY 40602

G. Dick

Department of Energy

Office of Fossil Energy

Washington, DC 20545

G. P. Dix

Department of Energy

Office of the Assistant

Secretary for Environment

Washington, DC 20545

2 DOE Public Document Room

Attn: Mr. R. A. Evans

Room G-298, Federal Building

P. 0. Box E

Oak Ridge, TN 37830
No. of

Copies

2 DOE Public Reading Room, FOI

Room IE-180, Forrestal Building

1000 Independence Avenue, SW

Washington, DC 20585

2 DOE Technical Information Center Customer Services Branch

P. 0. Box 62

Oak Ridge, TN 37830

2 DOE Public Document Room

Room G208

Oak Ridge Federal Building

Oak Ridge, TN 37830

2 DOE Public Reading Room

Room GA-142

Forrestal Building

1000 Independence Avenue, SW

Washington, DC 20585

30 A. P. Duhame 1

Department of Energy

Office of the Assistant

Secretary for Environment

EV-34, MS E-201 GTN

Washington, DC 20545

H. E. Dunn, Ph. D.

Indiana State University

Evansville

8600 University Boulevard

Evansville, IN 47702

L. Eaker

Office of Senator Percy

1200 Dirksen Building

Washington, DC 20515

C. W. Edington

Office of Health and Environmental Research

Department of Energy

Washington, DC 20545

C. Eifert

Office of Assistant Secretary

for Environment

Department of Energy

Washington, DC 20545 
No. of

Copies

H. Enoch

Kentucky Department of Energy

P. 0. Box 11888

Lexington, KY 40578

J. L. Epler

Oak Ridge National Laboratory

Biology Division

P. 0. Box Y

Oak Ridge, TN 37830

2 Evansville \& Vanderburgh County Public Library

Attn: Ann Pearson

22 Southeast 5 th Street

Evansville, IN 47708

J. K. Farley

Department of Energy

Washington, DC 20545

W. Fernald

Department of Energy

Office of Fossil Energy

RM F-317 GTN

Washington, DC 20545

J. Fillo

Environmental Research and Technology, Inc.

700 Fifth Avenue Building

Fourth Floor

Pittsburgh, PA 151219

J. Finucane

Energy Information Administration

Department of Energy

Mai1 Stop 7413

Federal Building

12th \& Pennsylvania Avenue NW

Washington, DC 20461

R. Fischer

Department of Energy

Office of Fossil Energy

Washington, DC 20545
No. of

Copies

A. Follett

Department of Energy

Office of Fossil Energy

Washington, DC 20545

S. Foster

Energy and Environmental Analysis, Inc.

1111 North 19th Street

Arlington, VA 22209

Larry Fradkin

Argonne National Laboratory

Building 12

Argonne, IL 60439

C. W. Gehrs

Oak Ridge National Laboratory

P. 0. Box E

Oak Ridge, TN 37830

A. Goldberg

1217 Forest Glen Road

Department of Energy

Silver Spring, MD 20901

G. Goldstein

Office of the Assistant Secretary for Environment

Department of Energy

Washington, DC 20545

M. Gottlieb

Department of Energy/ECT

Washington, DC 20545

A. Govan

Department of Energy

Office of Fossil Energy

Washington, DC 20545

M. Guerin

Oak Ridge National Laboratory

P. O. Box $X$

Oak Ridge, TN 37830

R. Hamilton

Department of Energy

Washington, DC 20545 
No. of

Copies

L. R. Harris

National Institute Occupational

Safety \& Health

Mail Stop 8A-45

5600 Fishers Lane

Rockville, MD 20852

2 B. Henschel

Environmental Protection Agency

401 M Street, SW

Washington, DC 20460

J. Hill

Ashland Synthetic Fuels, Inc.

P. 0. Box 391

Ashland, KY 41101

C. H. Hobbs

Lovelace Inhalation Toxicology

Research Institute

P. 0. Box 5890

Albuquerque, NM 87115

H. Hollister

Department of Energy

Office of Assistant Secretary

for Environment

Washington, DC 20545

P. House

Department of Energy/0TI

Washington, DC 20545

W. Hub is

Gulf Mineral Resources

1720 South Bellaire

Denver, CO 80222

2 K. James

Environmental Protection Agency

401 M Street, SW

Washington, DC 20460

J. Johnson

Department of Energy

Office of Fossil Energy

Washington, DC 20545
No. of

Copies

L. Joseph

Department of Energy

Office of Fossil Energy

Washington, DC 20545

R. A. Lewis

Department of Energy

Office of Assistant Secretary for Environment

EV-34, GTN

Washington, DC 20545

S. C. Lewis

Exxon Corporation

Research and Environmental

Health Division

Medical Department

P. 0. Box 235

East Millston, NJ 08873

A. Lloyd

Department of Energy

Office of Fossil Energy

Washington, DC 20545

M. J. Massey

Environmental Research and Technology, Inc.

700 Fifth Avenue Building

Fourth Floor

Pittsburgh, PA 15219

H. McCammon

Environmental Research Division

Department of Energy

Washington, DC 20545

R. 0. McClellan

Lovelace Inhalation Toxicology Research Institute

P. 0. Box 5890

Albuquerque, NM 87115

G. C. McGurl

SRC International, Inc.

P. 0. Box 3396

Englewood, CO 80155 
No. of

Copies

M. L. Mendelsohn

Lawrence Livermore Laboratory

University of California

P. 0. Box 808

Livermore, CA 94550

L. Miller

Department of Energy

Office of Fossil Energy

Washington, DC 20545

M. Minthorn

Department of Energy

Health Effects Research Division

Washington, DC 20545

D. Monti

Department of Energy/0TI

Washington, DC 20545

2 Morgantown Public Library

373 Spruce Street

Morgantown, WV 26505

J. L. Morris

Department of Energy

Office of Fossil Energy

MS E-333

Washington, DC 20545

J. Nardella

Department of Energy

Office of Fossit Energy

Washington, DC 20545

J. Norwood

International Coal Refining Co.

P. 0. Box 2752

Allentown, PA 18001

2 Owensboro-Davies County Public Library

Attn: Al ice G. Lewis

450 Griffith Avenue

Owensboro, KY 42301
No. of

Copies

\section{B. Pallay}

National Institute Occupational

Safety \& Health

5600 Fishers Lane

Rockville, MD 20852

M. Parmenter

Kerr-McGee Corporation

Kerr-McGee Center

Packaging \& Labeling Dept.

Oklahoma City, OK 73125

R. M. Perhac

Electric Power Research Institute

P. 0. Box 10412

Palo Alto, CA 93404

W. Piver

National Institute of Environmental Health Sciences

P. 0. Box 12233

Research Triangle Park, NC 27709

J. Reafsnyder

Department of Energy

Oak Ridge Operations

P. 0. Box $E$

Oak Ridge, TN 37830

C. Reilly

Biology Department

Argonne National Laboratory

9700 South Cass Avenue

Argonne, IL 60439

2 W. J. Rhodes

Industrial Environmental

Research Laboratory

MD-61, US EPA

Research Triangle Park, NC 27711

C. R. Richmond

Oak Ridge National Laboratory

P. 0. Box $X$

Oak Ridge, TN 37830 
No. of

Copies

D. K. Schmalzer

The Pittsburg \& Midway Coal Mining Co.

P. O. Box $3396^{\circ}$

Denver, CO 80155

E. Schmetz

Department of Energy

Office of Energy Technology

Mail Stop F-317

Washington, DC 20545

R. L. Scott

Department of Energy/PETC

4800 Forbes Avenue

Pittsburgh, PA 15213

C. Shih

TRWI Space Park

R42142

Redondo Beach, CA 90278

W. K. Sinclair

Argonne National Laboratory

9700 South Cass Avenue

Argonne, IL 60439

G. Stapleton

Department of Energy

Office of Health and Environmental Research

947 Paulsboro Drive

Rockville, MD 20850

R. Stern

NEPA

Office of the Assistant

Secretary for Environment

Washington, DC 20545

J. A. Strasser

Atlantic Coal Institute

P. 0. Box 1133

Sydney, Nova Scotia

CANADA BIP $6 \mathrm{~J} 7$
No. of

Copies

J. Talty

National Institute Occupational

Safety \& Health

5600 Fishers Lane

Rockville, MD 20852

J. Tao

International Coal Refining Co.

P. 0. Box 2752

Allentown, PA 18001

Evan Thayer

International Coal Refining Co.

P. 0. Box 2752

Allentown, PA 18001

R. V. Trense

Exxon Corporation

Environmental Affairs Programs

Exxon Research \& Engineering Co.

P. 0. Box 101

Florham Park, NJ 07932

2 University of Kentucky

Attn: J. Pivarnik

Government Publications Department

M. L. King Library

Lexington, KY 40506

G. K. Vick

Exxon Corporation

P. 0. Box 101

Florham Park, NJ 07932

G. L. Voelz

University of California

Los Alamos Scientific Laboratory

P. 0. Box 1663

Los Alamos, NM 97545

2 Library

West Virginia University

Downtown Campus

Attn: C. Hamerick

Morgantown, WV 26506 
No. of

Copies

K. Wilzbach

Argonne National Laboratory

9800 South Cass Avenue

Argonne, IL 60439

F. Witmer

Department of Energy/ECT

Washington, DC 20545

F. J. Wobber

Department of Energy

Environmental Research Division

Washington, DC 20545

R. W. Wood

Department of Energy

Physical and Technological Programs

Office of Health and Evironmental Research

Washington, DC 20545

\section{ONSITE}

2 DOE Richland Operations office

H. E. Ransom

M. G. White

125 Pacific Northwest Laboratory

L. E. Anderson

F. D. Andrew

W. J. Bair

R. M. Bean

C. D. Becker

F. G. Burton

W. C. Cannon

D. A. Cataldo

J. F. Cline

D. D. Dauble

H. Drucker (30)

R. M. Emery

W. E. Fallon

L. J. Felice

W. D. Fel ix

M. E. Frazier

R. H. Gray (30)
No. of

Copies

G. A. Halseth

D. R. Kalkwarf

M. T. Karagianes

B. J. Kelman

J. C. Kutt

S. M. Loscutoff

R. H. Lovely

D. D. Mahlum (25)

S. Marks

P. S. Mellinger

L. D. Montgomery

J. E. Morris

0 . R. Moss

T. Nelson

J. M. Nielsen

D. E. Olesen

T. L. Page

R. A. Pelroy

R. W. Perkins

M. R. Petersen

R. D. Phillips

T. M. Poston

H. A. Ragan

R. A. Renne

R. E. Schirmer

R. P. Schneider

D. M. Schoengold

M. R. Sikov

D. S. Sklarew

L. G. Smith

D. L. Springer

J. B. States

J. A. Strand

A. P. Toste

D. Tolley

B. E. Vaughan

B. A. Vieux

M. L. Warner

W. C. Weimer

R. E. Wildung

W. R. Wiley

D. H. Willard

C. Willey

B. W. Wilson

Biology Publications Office Technical Information (5)

Publishing Coordination (2) 
